\title{
D-Propranolol and DL-propranolol both decrease conversion of L-thyroxine to L-triiodothyronine
}

\author{
PAUL HEYMA， RICHARD G LARKINS， LINDA HIGGINBOTHAM， KONG WAH NG
}

\section{Summary and conclusions}

The effects of propranolol (DL-propranolol) and $D-$ propranolol on thyroid hormone metabolism were studied in six euthyroid volunteers receiving L-thyroxine (T4) and six hypothyroid patients receiving T4 replacement. D-propranolol as well as propranolol decreased Ltriiodothyronine (T3) concentrations and the ratio of T3 to $T 4$ in the euthyroid subjects, and D-propranolol decreased these variables in the subjects with hypothyroidism (propranolol was not given to this group).

It is concluded from this study and from parallel invitro investigations that the effect of propranolol on the conversion of $T 4$ to $T 3$ is unrelated to its beta-adrenergic blocking activity, and that at low therapeutic doses propranolol may exert appreciable "membranestabilising" effects in vivo.

\section{Introduction}

Decreased plasma concentrations of L-triiodothyronine (T3) after treatment with propranolol (DL-propranolol) have been well documented in euthyroid subjects, hyperthyroid patients, and hypothyroid patients receiving L-thyronine (T4) replacement. ${ }^{1-3}$ Propranolol inhibits the conversion of T4 to T3 by peripheral tissues, ${ }^{45}$ but the mechanism by which it exerts this effect is not clear.

We recently showed that both L-propranolol, the betablocking isomer, and D-propranolol, which is devoid of betablocking activity, directly inhibit production of T3 from T4 in vitro in an isolated rat renal tubule system. ${ }^{8}$ These in-vitro investigations suggested that this inhibition of conversion by propranolol is not related to the drug's beta-blocking action but due to its "membrane-stabilising activity." "The concentrations of propranolol used, however, were high, and the relevance of these in-vitro studies to use of the drug in vivo was not clear. Indeed, the membrane-stabilising actions of propranolol have been assumed to be unimportant at the usual therapeutic doses. ${ }^{7}$ We describe here investigations designed to determine whether D-propranolol also inhibits the conversion of T4 to T3 in vivo, thus showing whether the inhibition of this conversion depends on beta-adrenergic blockade.

\section{Subjects and methods}

Studies were carried out on six normal, euthyroid volunteers (three women and three men) and six middle-aged hypothyroid subjects (one woman and five men) receiving T4 replacement.

Blood samples were taken on day 1 from the six euthyroid volunteers, who then began taking $200 \mu \mathrm{g}$ of T4 daily throughout the study, which lasted 56 days. On day 14 blood samples were taken and Endocrinology Department, Royal Melbourne Hospital, Victoria
3050, Australia

PAUL HEYMA, PHD, endocrine biochemist

LINDA HIGGINBOTHAM, MB, FRACP, assistant endocrinologist

University of Melbourne Department of Medicine, Repatriation General Hospital, Heidelberg, Victoria 3081, Australia

RICHARD G LARKINS, PHD, FRACP, first assistant

KONG WAH NG, MB, BS, endocrinology registrar the subjects in group A (two women, one man) began taking propranolol (Inderal) $80 \mathrm{mg}$ twice daily while those in group B (one woman, two men) began taking D-propranolol $80 \mathrm{mg}$ twice daily. Blood samples were taken again on day 28 , when the subjects stopped taking the drugs. On day 42 blood samples were taken and the groups began two weeks' treatment with the other drug-that is, group A began taking D-propranolol and group B propranolol, both $80 \mathrm{mg}$ twice daily. Blood samples were obtained again on day 56, when the subjects stopped taking the drugs and T4.

The six patients who were receiving $\mathrm{T} 4$ replacement for hypothyroidism took D-propranolol $80 \mathrm{mg}$ twice daily for 14 days. Blood samples were taken and pulse rate and blood pressure measured before and after the course of tablets.

$\mathrm{T} 3, \mathrm{~T} 4$, and thyroid-stimulating hormone $(\mathrm{TSH})$ radioimmunoassays were performed on the plasma from each subject, and all samples were assayed together in each radioimmunoassay. T3 was measured as described, ${ }^{8}$ and $\mathrm{T} 4$ and $\mathrm{TSH}$ radioimmunoassays were performed using commercially available kits (Radiochemical Centre, Amersham, England; MRC 68/38 TSH standard).

Paired Student's $t$ tests were used for statistical evaluation of the results.

\section{Results}

Euthyroid volunteers receiving T4-Plasma T3 concentrations were significantly decreased after two weeks' treatment with propranolol $(\mathrm{p}<0.01)$ and $\mathrm{D}$-propranolol $(\mathrm{p}<0.05)$ (table I). Circulating $\mathrm{T} 4$ concentrations were not significantly changed after treatment with either drug. TSH concentrations were suppressed throughout the study. The ratio of $\mathrm{T} 3$ to $\mathrm{T} 4$ decreased significantly and to a similar extent during both periods of treatment ( $\mathrm{p}<0.02$ for both drugs).

Patients with hypothyroidism receiving T4 showed no change in pulse rate or blood pressure after two weeks' treatment with $\mathrm{D}$ propranolol (table II). Plasma concentrations of T3 were significantly

TABLE I-Mean $( \pm S E M)$ results of thyroid function tests before and after two weeks' treatment with propranolol and $\mathrm{D}$-propranolol in six normal volunteers receiving $200 \mu \mathrm{g}$ of $\mathrm{T} 4$ daily

\begin{tabular}{|c|c|c|c|}
\hline & $\begin{array}{l}\text { Basal } \\
\text { value }\end{array}$ & $\begin{array}{c}\text { After } \\
\text { treatment }\end{array}$ & Significance \\
\hline $\begin{array}{l}\text { T3 }(\mathrm{nmol} / 1) \\
\text { T4 }(\mathrm{nmol} / 1) \\
\text { T3: T4 }\left(\times 10^{2}\right) \\
\text { TSH }(\mathrm{mU} / \mathrm{l})\end{array}$ & $\begin{array}{c}3.6 \pm 0.1 \\
191 \pm 8 \\
1.95 \pm 0.08 \\
<0.5\end{array}$ & $\begin{array}{c}2.8 \pm 0 \cdot 2 \\
195 \pm 20 \\
1 \cdot 43 \pm 0.06 \\
<0.5\end{array}$ & $\begin{array}{c}p<0.01 \\
N S \\
p<0.02 \\
N S\end{array}$ \\
\hline $\begin{array}{l}\text { T3 }(\mathrm{nmol} / \mathrm{l}) \\
\text { T4 (nmol/1) } \\
\text { T3: T4 }\left(\times 10^{2}\right) \\
\text { TSH }(\mathrm{mU} / 1)\end{array}$ & $\begin{aligned} 3 \cdot 4 & \pm 0 \cdot 2^{D-} \\
202 & \pm 16 \\
1 \cdot 70 & \pm 0.09 \\
& <0.5\end{aligned}$ & $\begin{array}{c}2 \cdot 9 \pm 0 \cdot 1 \\
223 \pm 24 \\
1 \cdot 34 \pm 0.08 \\
<0.5\end{array}$ & $\begin{array}{l}p<0.05 \\
N S \\
p<0.02 \\
\text { NS }\end{array}$ \\
\hline
\end{tabular}

$\mathrm{T} 3=$ Triiodothyronine. $\mathrm{T} 4=$ Thyronine. $\mathrm{TSH}=$ Thyroid-stimulating hormone Conversion: SI to traditional units-T3: $1 \mathrm{nmol} / 1 \approx 0.65 \mathrm{ng} / \mathrm{ml}$. T4: $1 \mathrm{nmol} / 1 \approx$ $77 \cdot 7 \mathrm{ng} / 100 \mathrm{ml}$

TABLE II-Details of hypothyroid patients before and after two weeks' treatmen with D-propranolol

\begin{tabular}{|c|c|c|c|c|c|c|}
\hline \multirow[b]{2}{*}{$\begin{array}{l}\text { Case } \\
\text { No }\end{array}$} & \multirow[b]{2}{*}{$\begin{array}{c}\text { Age } \\
\text { (years) }\end{array}$} & \multirow[b]{2}{*}{$\underset{(\mu \mathrm{g} / \text { day })}{\mathrm{T} 4}$} & \multicolumn{2}{|c|}{$\begin{array}{c}\text { Pulse } \\
\text { (beats/min) }\end{array}$} & \multicolumn{2}{|c|}{ Blood pressure } \\
\hline & & & $\begin{array}{c}\text { Before } \\
\text { treatment }\end{array}$ & $\begin{array}{c}\text { After } \\
\text { treatment }\end{array}$ & $\begin{array}{c}\text { Before } \\
\text { treatment }\end{array}$ & $\begin{array}{c}\text { After } \\
\text { treatment }\end{array}$ \\
\hline $\begin{array}{l}1 \\
2 \\
3 \\
4 \\
5 \\
6\end{array}$ & $\begin{array}{l}64 \\
73 \\
67 \\
68 \\
60 \\
57\end{array}$ & $\begin{array}{l}150 \\
200 \\
100 \\
100 \\
100 \\
150\end{array}$ & $\begin{array}{l}72 \\
84 \\
68 \\
72 \\
66 \\
72\end{array}$ & $\begin{array}{l}72 \\
80 \\
70 \\
64 \\
56 \\
80\end{array}$ & $\begin{array}{l}160 / 100 \\
140 / 88 \\
170 / 100 \\
150 / 75 \\
150 / 90 \\
120 / 75\end{array}$ & $\begin{array}{l}160 / 100 \\
1555 / 85 \\
170 / 90 \\
160 / 80 \\
138 / 80 \\
130 / 80\end{array}$ \\
\hline
\end{tabular}


decreased $(p<0.02)$ but those of T4 remained unchanged after the treatment (figure). The ratio of T3 to T4 was significantly depressed after treatment $(p<0.02)$. TSH concentrations did not change significantly.
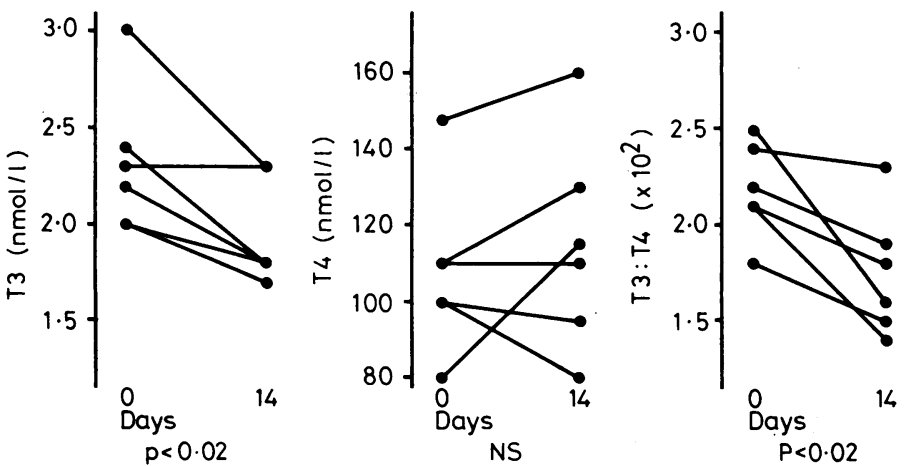

Concentrations of T3 and T4 and ratio of T3 to T4 in six hypothyroid subjects receiving $\mathrm{T} 4$ replacement before and after two weeks' treatment with D-propranolol.

Conversion: SI to traditional units-T3: $1 \mathrm{nmol} / 1 \approx 0.65 \mathrm{ng} / \mathrm{ml}$. T4: $1 \mathrm{nmol} / 1 \approx 77 \cdot 7 \mathrm{ng} / 100 \mathrm{ml}$.

\section{Discussion}

Propranolol has been widely used for almost a decade to provide symptomatic relief of thyrotoxicosis. ${ }^{\circ}$ Its beneficial effects are largely attributed to beta-adrenergic blockade. Recently, propranolol has been shown to affect the concentration of T3 in the circulation, ${ }^{410}$ although it has no effect on thyroid hormone secretion. ${ }^{11}$ The decrease in T3 concentration is due to inhibition of the conversion of $\mathrm{T} 4$ to $\mathrm{T} 3$ by the peripheral tissues, ${ }^{45}$ and this reduced conversion during propranolol treatment may explain some of the beneficial effects of propranolol in thyrotoxicosis. ${ }^{1}$ We have shown a decrease in T3 concentrations and in the ratio of $\mathrm{T} 3$ to $\mathrm{T} 4$ during propranolol treatment, confirming these reports.

In-vitro studies ${ }^{6}$ showed that both $\mathrm{D}$ - and L-isomers of propranolol inhibit formation of $\mathrm{T} 3$ from $\mathrm{T} 4$ by isolated rat renal tubules, indicating that the inhibition of the deiodination of T4 to T3 by propranolol is probably not due to the drug's beta-blocking action. Furthermore, the effect of both isomers was reproducible by quinidine, showing that it was a "membrane-stabilising" or "quinidine-like" effect.

The present studies show that T3 concentrations and the ratio of T3 to T4 fell when D-propranolol was given to normal subjects receiving $\mathrm{T} 4$ and hypothyroid subjects receiving $\mathrm{T} 4$ replacement. Thus the in-vitro data are relevant to man and propranolol decreases conversion of $\mathrm{T} 4$ to $\mathrm{T} 3$ by an effect that is independent of beta-adrenergic blockade and is probably related to the drug's membrane-stabilising activity. The lack of effect of D-propranolol on pulse and blood pressure together with a chemical analysis by the manufacturer showed that the D-propranolol tablets did not contain any appreciable amount of L-propranolol. That the effect occurred in both groups studied (normal subjects with suppressed TSH secretion and hypothyroid subjects receiving T4 replacement) indicates that it was not due to altered secretion from the thyroid gland. In-vitro studies showed that it was not due to a change in the stability of $\mathrm{T} 3$, and also that the preparation of D-propranolol used was devoid of beta-adrenergic blocking activity.

The mechanism by which the membrane-stabilising actions of propranolol affect the conversion of T4 to T3 is not clear. Recent studies, however, show that the outer ring deiodinase that effects the conversion is associated with the plasma membrane, 1213 raising the possibility that drugs that act on the membrane directly affect the activity of the enzyme. Alternatively, the effect might be mediated by changes in ion fluxes or other membrane-dependent effects.
We think that this is the first time that appreciable membranestabilising actions of propranolol have been observed in man at low therapeutic doses. It does not necessarily follow that the major mechanism of the beneficial effect of propranolol in man is its effect on the conversion of T4 to T3 or that D-propranolol would be as effective as the beta-blocking L-isomer in symptomatically treating this condition. Clearly, though, low doses of the D-isomer of propranolol can have important biological effects.

We wish to thank Imperial Chemical Industries for generously supplying the D-propranolol tablets. According to the certificate of analysis, these tablets contained no L-propranolol.

\section{References}

1 Lotti G, Delitala G, Devilla L, Alagna S, Masala A. Reduction of plasma triiodothyronine (T3) induced by propranolol. Clin Endocrinol 1977;6: 405-10.

2 Saunders J, Hall SEH, Crowther A, Sonksen PH. The effect of propranolol on thyroid hormones and oxygen consumption in thyrotoxicosis. Clin Endocrinol 1978;9:67-72.

3 Lumholtz IB, Siersbaek-Nielsen K, Faber J, Kirkegaard C, Friis T. Effect of propranolol on extrathyroidal metabolism of thyroxine and 3,3',5-triiodothyronine evaluated by noncompartmental kinetics. f Clin Endocrinol Metab 1978;47:587-9.

4 Harrower ADB, Fyffe JA, Horn DR, Strong JA. Thyroxine and triiodothyronine levels in hyperthyroid patients during treatment with propranolol. Clin Endocrinol 1977;7:41-4.

5 Verhoeven RP, Visser TJ, Docter R, Hennemann G, Schalekamp MADH. Plasma thyroxine, 3,3',5-triiodothyronine and 3,3'5'-triiodothyronine during beta-adrenergic blockade in hyperthyroidism. $f$ Clin Endocrinol Metab 1977;44:1002-5.

${ }^{6}$ Heyma P, Larkins RG, Campbell DG. Inhibition by propranolol of 3,5,3'-triiodothyronine formation from thyroxine in isolated rat renal tubules: an effect independent of beta adrenergic blockade. Endocrinology (in press).

7 Nickerson M, Collier B. Drugs inhibiting adrenergic nerves and structures innervated by them. In: Goodman LS, Gilman A, eds. The pharmacological basis of therapeutics. New York: MacMillan Publishing Company, 1975:533-64.

8 Heyma P, Larkins RG, Stockigt JR, Campbell DG. The formation of triiodothyronine and reverse triiodothyronine from thyroxine in isolated rat renal tubules. Clin Sci Mol Med 1978;55:567-72.

Shanks RB, Hadden DR, Lowe DC, McDermitt DG, Montgomery DAD. Controlled trial of propranolol in thyroxtoxicosis. Lancet $1969 ; \mathrm{i}: 993-4$.

10 Murchison LE, Bewsher PD, Chesters MI, Ferrier WR. Comparison of propranolol and practolol in the management of hyperthyroidism. Br $\mathcal{F}$ Clin Pharmacol 1976;3:273-7.

11 Wartofsky L, Dimond RC, Noel GL, Frantz AG, Earll JM. Failure of propranolol to alter thyroid iodine release, thyroxin turnover, or the TSH and PRL responses to thyrotrophin-releasing hormone in patients with thyrotoxicosis. F Clin Endocrinol Metab 1975;41:484-90.

12 Leonard JL, Rosenberg IN. Subcellular distribution of thyroxine 5'-deiodinase in the rat kidney: a plasma membrane location. Endocrinology 1978;103:274-80.

13 Maciel RMB, Ozawa Y, Chopra IJ. Subcellular localization of thyroxine and reverse triiodothyronine outer ring monodeiodinating activities. Endocrinology 1979;104:365-71.

(Accepted 26 March 1980)

ONE HUNDRED YEARS AGO A lady requested me to visit Mrs D of Coleraine, who had once been a servant in her house. I went, and found as follows. Mrs D, aged 40, was the mother of four children. On December 22nd, 1879, she was taken ill in labour, without any apparent cause, about a fortnight before the time when she expected to be confined. She was attended by a midwife, and was safely and easily delivered of a male child. The placenta came away without any trouble, and seemed to be all right; there was no haemorrhage. The child seemed to be perfectly formed, with perfect nails, but was remarked to be rather small and weak; it died in six hours. After this, the mother never became healthy or natural in appearance. She was supposed to be dying in dropsy. The whole affair, however, was cleared up by the birth of a fine well-grown healthy daughter February 4th. Mother and baby are both doing well. There were just forty-four days between the birth of the two children. JAMES C L CARSON. (British Medical fournal, 1880.) 